\title{
The Protection of Women and Children as Victims of Human Trafficking in Jambi Province
}

\author{
Hafrida ${ }^{\star}$; Nelli Herlina ${ }^{\star \star}$; Zulham Adamy ${ }^{\star \star \star}$ \\ Faculty of Law, Universitas Jambi \\ ^hafrida_hukum@unja.ac.id

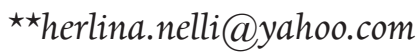 \\ ${ }^{\star \star \star}$ zulham.adamy@yahoo.com
}

\begin{abstract}
The research aims at studying the policy of the Regional Government in protecting the victims of human trafficking, especially females and children. This legal research is based on an empirical study at Regional Police (POLDA), P2TP2A, and Social Services office in Jambi Province. The Law Number 35/2014 on the Amendment of The Law Number 23/2002 on Child Protection provides a greater portion for the Regional Government to take active roles in providing child protection and Presidential Regulation Number 69/2008 about Task Force Prevention and Handling the Criminal Act of Trafficking Victim. Using analysis of descriptive qualitative, it is learned that the handling of the women and children as victims of trafficking remain partially. The responsible institutions have not well-coordinated because a task force as commissioned by Presidential Regulation number 69/2008. The results show that Jambi Province has passed Jambi Province Regional Regulation Number 2/2015 on Prevention and Handling of $\mathrm{Hu}-$ man Trafficking towards Females and Children. However, the study also shows that the regulation has not been applied by related parties since Governor's regulation as implementing regulation is inexistent.
\end{abstract}

Keywords: Human Trafficking, Victims, The Protection Women and Children 


\section{A. Introduction}

Human trafficking is one kind of violation against human rights by treating human/victims as a mere commodity that can be purchased, sold, and resold. Human is treated as an object or a property by the traffickers in order to get money and personal gains. Human traffickers never care about the conditions of the victims. Instead, for them the most important thing is only the benefit gained from their act of human trafficking. Human traffickers follow several modes of action to trap their victims, especially females and children coming from underprivileged and low educated society.

Human trafficking, according to Article 3 of UN Protocol, is defined as:

Human Trafficking/Trafficking in persons shall mean the recruitment, transportation, transfer, harbouring or receipt of persons, by means of the threat or use of force or other forms of coercion, of abduction, of fraud, of the abuse of power or of a position of vulnerability or of the giving or receiving of payments or benefits to achieve the consent of a person having control over another person for the purpose of exploitation. ${ }^{1}$

The purpose of exploitation as mentioned above has a very wide meaning, referring to both economic and sexual exploitation. In various cases, females and children as the victims of human trafficking suffers from complex exploitations, both sexual exploitation for the purpose of economic exploitation and even slavery. For the purpose of exploitation, various modes of recruitment were used, for example by persuasion to teenagers, usually in shopping malls, by offering them luxurious things and money.

Victims are traded not only for the purpose of prostitution and other types of sexual exploitation, but also for other types of exploitations, for example, forced labour, slavery, and other acts resembling slavery. The actors of human trafficking do the recruitment, transportation, transfer, harbouring or receipt of of persons for the

1 Article 3 of UN Protocol to Prevent, Suppress and Punish Trafficking in Persons, Especially Women and Children was signed in December 2000, in Palermo, Sicily, Italy. 
purposes of framing, or exploiting them in and axt of exploitation in many forms by means the threat or use of force or other forms of coercion, of abduction, of fraud, of the abuse of power or of a position of vulnerability or of the giving or receiving of payments or benefits to achieve the consent of a person having control over another person.

In the report of US state department on the human trafficking in 2011, Indonesia was categorized in the second layer in fulfilling the standards of protection against trafficking in persons (TPPO). Indonesia was considered as a main source of human trafficking of females, children, and males, both for sexual slavery and forced labour. According to the data released by Indonesian government, as cited in that report, around six millions of Indonesian citizens became migrant workers overseas, including 2.6 million workers in Malaysia, and 1.8 million in Middle East. Of the total number of migrant workers, 4.3 millions held official documents, while the 1.7 million were categorized as illegal workers. About 69 percent of Indonesian workers were females. ${ }^{2}$

In Indonesian Law, human trafficking as regulated by Law Number 1 Year 2007 on the Suppression of Criminal Acts of Human Trafficking is defined as:

Article 1 (Section 1): An act of recruiting, transportation, or receipts of persons by means of threat, use of force, abduction, captivity, forgery, fraud, abuse of power, of a position of vulnerability, of debt bondage or of the giving or receiving of payments or benefits to achieve the consent of a person having control over another person, carried nationally or transnationally for the purpose of exploitation or resulting in a person being exploited.

Article 1 (Section 2); An act of human trafficking as every act or a series of acts fulfilling all elements of criminal acts as regulated in this act. (The legal substance is formal in nature because based on exhibit of the purposes of human trafficking, a judge can penalize a person

Based on the above definitions, human trafficking is understood

2 Report of US State Department on Human Trafficking in 2012, cited by Elsa R.M. Toule and Sherly Adam in "Tindak Pidana Perdagangan Orang di Indonesia Sebuah Catatan Kritis 
as comprising 3 (three) elements serving as the foundations of an act of human trafficking. In case of adults becoming the victim, the elements of trafficking that should be considered are the process, method, and purposes. Process refers to the act of recruitment, transportation, and receipt and methods refer to threat, use of force, abduction, deception, fraud, abuse of power, of position of vulnerability, debt bondage, or the giving or receiving of payments or benefits to achieve the consent of a person having control over another person, carried nationally or transnationally. In addition, the purpose of exploitation also needs to be considered. If the process of becoming victims of human trafficking is proven to be done through recruitment, transport, transfer, harbouring, and receipt is evidential, someone is considered to be a victim of trafficking. Meanwhile, the element of method is whether the persons undergo threat or other force by means of abduction, deception, fraud, or abuse of power. If they do, them it is considered as human trafficking. Furthermore, from the aspect of purposes, are the victims exploited, for example, for prostitution, other form of sexual exploitation, labour force, slavery, and other instances of slavery (for example: forced conscription), or extractions of body organs. If all these elements are found, someone is confirmed to be a victim of human trafficking.

Human trafficker is defined as someone doing, being involved or giving a consent on the activities of recruitment, transport, trade, transfer, receipt or harbouring someone from one place to another place for the purposes of gaining benefits. Victims of human trafficking is a person recruited, transported, purchased, sold, transferred, receipt, or harboured, as defined by trafficking in persons, especially on children, with or without their consent. The core of human trafficking is the element of exploitation and benefit gaining by one of the parties. Exploitation here is defined as oppression, extortion, and use of someone physically, sexually, of their labour and skills by someone else by minimally use of force or fraud to gain a bigger benefit by one of the party.

In Indonesia, UN Protocol on Trafficking in Persons has been adopted in National Action Plan (RAN) on Supresion of Trafficking 
on Females and Children. RAN is supported by Indonesian Presidential Decree Number 88 Year 2002, which define trafficking in persons especially female and children as any acts of the traffickers containing one of the act of recruiting regionally, and transnationally, transfer, transport, receipt, harbouring temporarily or in the destination, of female and children, by means of threat, use of verbal and physical force, abduction, deception, fraud, use of position of vulnerability (for example when one does not have any other option), isolation, drugs addiction, debt bondage, giving or receiving payment or benefit, where females and children are used for prostitution and sexual exploitation (including paedophilia), legal or illegal migrant labours, child adoption, formal work, arranged marriage, housemaid, beggar, pornography industry, drugs trade, sale of human organs, and other forms of exploitation.

Victims of human trafficking should be protected because first, society is considered as an entity of system of institutionalized trust. This trust is integrated with norms expressed in form of structured institutions such as police, attorney, and court, and so on. The crimes happening to the victims will mean the destruction of this system of trust. Therefore criminal laws and other kinds of law related to the victims will function as a medium of rebuilding trust on the system. The second is an argumentation of social contract and social solidarity because government can be considered as monopolizing all social reactions against crimes and prohibition of personal acts. Therefore, government should provide cares for the victims by improving the services for them and regulating their rights. Third, victim protection is commonly associated with one purpose of criminal law, that is conflict resolution. Conflict resolution as a result of criminal law will recover balance and create peace in society ${ }^{3}$.

Geographically, Jambi Province is located in a strategic position in the middle of Sumatera Island, bordered on the North by Riau Province, East by South China Sea, South by South Sumatera

3 Muladi, "Perlindungan Korban dalam Sistem Peradilan Pidana", as published in Kumpulan Karangan Hak Asasi Manusia, Politik dan Sistem Peradilan Pidana, (Semarang: Badan Penerbit Universitas Diponogoro, 1997), p. 172. 
Province, and West by West Sumatera Province. The position of Jambi Province is quite strategic because it is located near Economic Growth Region, i.e. IMSGT (Indonesia, Malaysia, Singapura Growth Triangle). Besides, Jambi sees a future opportunity by the establishment of Thai Pass (previously called as Kra Pass or Kra Isthmus Pass), i.e. a pass crossing Southern Thailand to shorten the transportation time in that area. This will open a new opportunity to Jambi Province because of its position directly facing and open to South China Sea. The opening of Kra Pass will change the global geo economy (especially East Asia) considering that sea transport route which currently passes Malaka Strait, will directly change to Kra Pass Besides, Sabang port in the west end of Indonesia can potentially be a large port facing directly to South China Sea.

This geographic situation on the one hand will give a positive impact on the economic growth of Jambi Province. On the other hand, however, this situation will also open an opportunity for human trafficking in Jambi Province. Therefore, in 2015, Jambi Province Government passed a Regional Regulation of Jambi Province Number 2 Year 2015 on Prevention and Handling of Victims of Females and Children Trafficking. This regional regulation is passed in order to prevent and countermeasure human trafficking, threat, use of force, extortion and/or acts of demeanor on females and children as victims of human trafficking. Therefore handling and protection for females and children from any forms of human trafficking is needed; that protection provided by Local Government is aimed at regulating and serving the interests of the society, particularly females and children as victims of human traffickers.

In the local regulation, several responsibilities and authority of local government in providing protection for females and children in human trafficking, for example by Regional Action Plan, as shown in the following articles:

First Section of Regional Action Plan

Article 16:

(1) Regional Government is authorized to prepare a Regional Action 
Plan on prevention, handling and rehabilitation of victims of human trafficking

(2) The Regional Action Plan as referred by Article (1) includes strategic plans comprising:

a. Establish strategic alliance with various institutions or related sectors, and stakeholders in building mutual commitment to use the Regional Action Plan as the foundation by policy makers in the sectors of economics, employment, education, population, tourism and other related sectors.

b. Strengthen the coordination with local government (city and regency) and other provinces for prevention, handling, and rehabilitation of female and children victims of human trafficking in regions.

c. Conduct provision and expansion of financial resources to support Local Action Plan on prevention of female and children victims of human trafficking, and

d. Establish strong collaborative network with society, religious leaders, independent researchers, non-governmental organization, universities, international institutions, in conducting Regional Action Plan as collaborative programs.

(3) Further details on Regional Action Plan as referred in article (1) and (2) will be regulated by Governor Regulation.

This research is aimed at studying the regional policy of Jambi Province as a follow up in providing protection and prevention for human trafficking against females and children.

Based on the above discussion, the problems of this research are formulated as follows (1) How is the local government policy to preventing and protecting the victims of female and children trafficking as a follow up of Regional Regulation Number 2 Year 2015 on Prevention and Handling of Victims of Human Trafficking on Females and Children?; (2) What problems do Jambi Province government have in providing Jambi regional policy in preventing and protecting the victims of female and children trafficking; (3) How does Jambi Province government deal with the problems in preventing and protecting the victims of female and children trafficking. The objectives of the re- 
search are formulating as follows (1) To comprehend the policy of Local Government as a follow up of Regional Regulation Number 2 Year 2015 on Prevention and Handling of Victims of Human Trafficking on Females and Children in preventing and protecting the victims of female and children trafficking; (2) To comprehend the problems faced by Jambi Province government in providing Jambi regional policy in preventing and protecting the victims of female and children trafficking; (3) To comprehend the efforts of Jambi Province government in solving the problems in preventing and protecting the victims of female and children trafficking.

\section{B. Review of Related Literature}

Various research and scientific papers with the object of human trafficking from different aspects / perspective have been conducted. The issue of human trafficking have become important to discuss because this problem involves many actors and it is transnational in nature. The transnational trait is understood as involving many countries so that in solving this problem, a strong collabouration is required. Based on the data issued by United Nations in 2010, trafficking in persons is ranked as the third biggest criminal corporate transnationally.

One study by Terry Irenewati et. al. lists several factors causing human trafficking, i.e. poverty, low education, cultural issues related to the role of female in a family, relative power and status, role of children, gender-biased laws, as corruption. Types of trafficking also include long work hours, absence of recess time, illegal abduction, unpaid salary, sexual abuse, lack of decent accommodation, lack of decent food, prohibition of religious practices. ${ }^{4}$ Furthermore, in her thesis, Yustika Citra Mahenda mentioned the weak security implemented by countries is caused by four factors. First, the discrepancy of the responses from each country in facing the issues of human trafficking. Second, The bureaucracy and institutions in ASEAN

4 Terry Irenewaty, Nur Hidayah, Taat Wulandari. Analisis Gender Atas Kerentanan Perempuan Dan Anak Terhadap Praktek Trafficking. Fis 2007 
levels are not ready in counter measuring the issues of human trafficking. Third, the different perspectives of each country regarding domestic issues. In fact, ASEAN countries consider this issue as not really important to discuss in their national level. According to data from IOM (International Organization of Migration) in 2010, over 200,000 people became victims of human trafficking in Southeast Asia. Besides, according to report from US Department of States in 2010, Southeast Asia region is categorized as a region which has not maximally deal with human trafficking. It is proven by the fact that until 2010, only five countries have ratified laws on human trafficking, they are The Phillipines, Brunai, Myanmar, Cambodia, and Indonesia. ${ }^{5}$ Research on factors of trafficking has also been conducted, for example a study on trafficking factors conducted by Ari Satriani. ${ }^{6}$ The results show that the main cause of problems of recruitment is disharmony in family and free relationship. Furthermore, the modus operandi used by trafficker to trap a victim is by persuasion, offering high salary to victims, in a very well-organized way. Besides, counsellor function has not been maximal and needs to be improved in order to prepare female teenagers in high school to be ready for globalization era.

The latest study report of International Labour Organization (ILO) titled A Global Alliance against Force Labour can depict how high the number of the victims and how big the financial gain from human trafficking. ILO gave a figure of 2.45 millions people all over the world becoming victims of human trafficking, and approximately 32 billion US dollars of profit generated from human trafficking. The report added that 2.4 million to 3.7 million was at risk of being trapped by force labour and human trafficking because they worked as migrant labours, domestic assistant, and sex workers. ${ }^{7}$ This aware-

5 Yustika citra Mahendra: Thesis, Hubungan Internasional UGM, 2010.

6 Riszka Ari Satriani Studi Tentang Perdagangan Manusia (Human Trafficking) Pada Remaja Putri Jenjang Sekolah Menengah Di Kota Surabaya Study Of Human Trafficking In Adolescent Girl Secondary School Level At Surabaya Bimbingan dan Konseling, Fakultas Ilmu Pendidikan, Universitas negeri Surabaya, Jurnal BK Unesa. Volume 04 Nomor 1 Tahun 2013. 67-78)

7 ILO 2005 
ness of UN on a new form of human slavery apparently against human rights has been manifested into conventions such as Convention for the Suppression of the Traffic in Persons and of the Exploitation of the Prostitution of Other, International Convention for the Suppression of Traffic in Women and Children, Supplementary Convention on the Abolition of Slavery, the Slave Trade, and Institutions and Practices Similar to Slavery, International Convention for the Suppression of Traffic in Women of Full Age, and Convention on the Elimination of all Forms of Discrimination Against Women. All of these UN conventions imply that trafficking of females and children is considered as a transnational crime. As stated in a number of studies $^{8}$, female trafficking occurs transnationally, is well-organized, and involve various parties (personals, criminal organizations, even security forces and government apparatus) from sending and receiving countries

One of the theories about the causes of trafficking is the theory of intersectionality, developed by black feminists, assume that the previous feminism theories were heavily-oriented toward white females. ${ }^{9}$ In a chapter on Modern Feminism Theory, intersectionality is summarized as: all females are potentially opresed due to their gender, however the characteristics of the oppressions will be different depending on different intersections of imbalance as a vector of oppression and privilege. Ritzer further states (2005:447) that vector of oppression and privilege includes, among other, race, social class, gender, age, global location, and sexual preference. Meanwhile Tong(1983), in a chapter on Multicultural and Global Feminism, states that Ritzer's 'intersection' as a 'multi layered danger' and 'interlocking systems of oppression' from racism, secularism, sexism, and classism, inseparable of one another. Cossins ${ }^{10}$ on the other hand prefers naming it as 'convergent analysis' of sex and race. Furthermore, to sum up, intersectionality according to Association for

8 Jurnal Kriminologi Indonesia Vol. 4 No. I September 2005 : 7 - 13

9 Cossins, 2003: 144-156; Ritzer dan Goodman, 2005: 443-448 dan Tong, 1998: 315-330)

10 Jurnal Kriminologi Indonesia Vol. 4 No. I September 2005 : 7 - 13 
Women's Rights in Development (AWID) in its publication (2004:2) is every person possessing multiple and multi-layered self-identities as a result of social relations history, and the operation of structure of power. Darling (2002:3) states in detail the self-identities and intersection factors as: race, skin colour, caste, age, language, ancestry, good/bad, sexual orientation, religion, socio economy class, abled/ disabled, culture. In addition, Darling classifies the trafficked humans as a group of people specially at risk of suffering from multiple discrimination. Furthermore, Darling believes that females as victims of human trafficking have been denied from a place where they could hope for support and empowerment. For the purpose of this papers, Indonesian females and children as victims of human trafficking can be categorized as suffering from gender and economy discrimination.

The approach used in this research is normative juridical (Legal Research) or normative research. ${ }^{11}$ This research needs conceptual approach, normative approach, and case approach. These three approaches are selected on the basis of empirical study on the policy on protection of females and children as victims of human trafficking.

The source of data in this research is secondary data gathered from library research aimed at finding concepts, theories, information, and conceptual thoughts from previous studies, from legal documents and other scientific paper. The collect data method: This juridical normative research uses secondary data gathered from li-

11 With regards to this legal research, according to Ronny Hanitijo Soemitro: In fact, whenever a person mentions legal research, what he/she usually means is normative legal research, that is legal research implementing methods, approaches, theories / concepts, and methods of analysis comprising as normative law discipline) (Ronny Hanitijo Soemitro, "Peran Metodologi Dalam Pengembangan Ilmu Hukum”, Masalah-Masalah Hukum, Majalah FH Undip No. 5-1992, ISSN No. 0126-1389, hlm. 35). It is further stated that in normative legal research, there are 5 types of normative research, i.e.: (1) positive law inventory; (2) research aimed at discovering legal principles and research on legal principles; (3) clinical legal research or research aimed at discovering in-concreto law; (4) research on systematic intern of positive laws; (5) research on vertical and horizontal synchronization phases of positive laws. 
brary research as a method of collecting data based on the literatures previously prepared and are relevant to the research problems. The analyzing data is carried out by selecting legal articles and legal articles and legal principles regulating.

\section{Discussions}

The concept of SIJORI triangle between Singapore, Johor, and Indonesia puts Jambi Province in a strategic position as a traffic lane between three countries. From economic aspect, this condition give a beneficial impact. However, on the other hand, Jambi Province is open to possibilities for criminal acts including human trafficking. Indonesian Child Protection Commission (KPAI)'s commissioner on Trafficking and Exploitation affair, Ai Maryati Solihah ${ }^{12}$ expressed her concern on trafficking cases in Indonesia, where every year, there are 600 to 800 millions victims of human trafficking.

Human trafficking is one of the crimes undergoing the fastest growth in the world. Today human trafficking is also included as the biggest crimes in the world that calls for countermeasures because of the resulting impacts not only in economic aspects, but also, politics, cultural, and humanities ${ }^{13}$.

Observing this condition, in 2015 Jambi Province government passed a regional regulation on protection of the victims through Regional Regulation Number 2 Year 2015 on Prevention and Handling Victims of Females and Children Trafficking. In the Consideration section of the Regional Regulation, it is stated that: in order to prevent and countermeasure human trafficking, threat, and use of force, extortion, and/or acts of demeaning dignity and humanity against females and children as victims of human trafficking, it is deemed necessary to provide services and protections for females and children from human trafficking; that protection provided by the Regional Government is aimed at regulating and serving the interests

12 KPAI Website, accessed on 17 Oktober 2017.

13 Mahrus Ali dan Bayu Aji Pramono, 2011, Perdagangan Orang: Dimensi, Instrumen Internasional Dan Pengaturannya Di Indonesia, Citra Aditya Bakti, Bandung, p. 1 
of society, especially females and children as victims of human trafficking; that based on the consideration as referred by letter a) strategic position as a traffic lane between the borders of three countries, letter b) and c), it is deemed necessary to pass a Regional Regulation on Prevention and Countermeasures of Victims of Human Trafficking of Females and Children.

Article 1 section 10 of the Regional Regulation states that $\mathrm{Hu}-$ man Trafficking is defined as: Human Trafficking is an act of recruitment, transport, harbouring, transfer, or receipt of persons by means of threat, use of force, abduction, fraud, deception, abuse of power or vulnerability of position, debt bondage, or giving and receiving of payments or benefit, to achieve the consent of a person having control over another person, carried out nationally or transnationally, for the purpose of exploitation or causing someone to be exploited. Still in Article 1 Section 16, it is stated that "preventive action" is a direct attempt conducted by Regional Government to prevent human trafficking through supervision, permission, construction, and control. Furthermore, "Handling for Victims of Human Trafficking" is defined as an integrative attempt for saving, sheltering, assistance, and report". Based on the above definition, handling for victims of human trafficking should be carried out integrative and coordinated between all related parties, meaning this handling cannot be carried out by only one or two institutions.

Article 2 and 3 of this Regional Regulation regulates the purposes and aims. Article 2 mention the purpose of prevention and handling of victims of female and child trafficking is to provide protection for females and children from exploitation and slavery denying the rightful position of human as subject of law and causing problems of humanities demeaning dignity and privilege of human kinds.

Article 3. Prevention and Handling for Victims of Human Trafficking of females and children aims at:

1. To provide early prevention against any kinds of trafficking of females and children either for particular jobs or commercial sex activities.

2. To provide protection for females and children from criminal act of 
human trafficking

3. Rescue and rehabilitate the victims of human trafficking of females and children

4. Pass a sanction to the actors and all parties supporting the human trafficking of females and children.

5. Provide sense of security for females and children as victims of human trafficking, and

6. To recover the physical, non-physical, and economy of females and children as victims of human trafficking, especially females and children

The authority of Regional Government is regulated in Article 7. In order to prevent and handle the victims of female and child trafficking, Regional Government is authorized to:

1. Carry out any effort to prevent the crime of human trafficking in all its forms;

2. Provide and carry out integrated services for the victims;

3. Ensure the actions of protection of victims by considering the rights of parents, guardian, spouses, or other people legally responsible for the victims;

4. Supervise management of services for victims with the standard of services involving the society; and

5. Open access of information for females and children as victims of human trafficking.

The authority of regional government is further elabourated in the subsequent articles. Article 13 regulates the acts of handling for victims of human trafficking, i.e.:

(1) Handling for females and children as victims of human trafficking provided through:

1. The pick up, sheltering, and assistance for victims of human trafficking based on victims' domicile

2. Coordination with Local Government of Regency/City of the victim's residence for the process of returning of the victims to 
their domicile

3. Reporting of a criminal act of human trafficking to the authorized law enforcers in accordance with laws and regulations; and

4. All females and children as victims of human trafficking should be provided with services including psychological and medical counselling, and legal assistance and provision of skills and education, and alternatives

(2) In handling the victims, some principles should be followed:

a. Free of charge

b. Fast and accurate

c. Safe

d. Emphatic

e. Non-discriminative

f. Integrated

g. Non-judgement to the victims

(3) In counter-measuring human trafficking especially on females and children happening overseas and/or domestically, cooperation between regions is established based on the laws and regulations.

(4) Further regulation on guidelines of techniques in handling victims of human trafficking in females and children is regulated in Governor Regulation.

The provision of article 13 section (4) states further regulation on the guidelines of techniques in the handling of females and children as victims of human trafficking should be regulated by Governor Regulation, and the result of the research show that up to now the regulation is inexistent.

Furthermore, Article 16 of the Regional Regulation regulates the Regional Action Plan:

(1) Regional Government holds the authority in arranging regional action plan on prevention, handling, and rehabilitation of the victims human 
trafficking.

(2) Regional Action Plan as referred in section (1) comprises strategic plans including:

a. Establishing a strategic alliance with all institutions or related sectors, and with the stakeholders in order to build mutual commitment to use Regional Action Plan as a platform in policy making in the sector of economy, labour works, education, population, tourism and other related sectors;

b. Strengthening the coordination with the local government of Regency/City and other provinces in order to prevent, treat, rehabilitate females and children as victims of human trafficking in the region.

c. Doing some efforts in providing and expansion of financial resources to conduct Regional Action Plan in treating females and children as victims of human trafficking; and

d. Establishing strong cooperative networking with society, religious leaders, independent researchers, non-government organizations, universities, international institutions, in implementing programs of Regional Action Plans together.

(3) Further regulation on Regional Action Plane as referred by Section (1) and (2) is regulated by Governor Regulation.

Governor regulation on the guidelines of Reginal Action Plan as regulated by Article 16 section (3) has been established until now.

Meanwhile, according the regulation of Indonesian Coordinating Minister for Human Development and Cultural Affairs Number 2 Year 2016 on National Action Plan on Suppression of Trafficking in Persons 2015-2019, it is stated that: "The content of RAN PTPPPO as referred by section (1) include action plans for suppression of trafficking in person categorized into the following program clusters as follows:

a. Prevention and Child Participation, with Ministry of Cultural Issues as the institution in charge;

b. Health Rehabilitation, with Ministry of Health as institution in charge;

c. Social Rehabilitation, Return, and Social Reintegration, with 
Ministry of Social Affairs as institution in charge;

d. Establishment of Legal Norms, with Ministry of Law and Human Rights as institution in charge;

e. Law Enforcement, with Indonesian National Police (POLRI) as institution in charge;

f. Coordination and Collaboration, with Ministry of Manpower as institution in charge.

This is in line with National Action Plan on Abolition of Human Trafficking of Females and Children (RAN P3A). The main aim of RAN-P3A is: "The abolition of all forms of human trafficking on females and children".

Meanwhile, the particular aims are:

1. Availability of legal norms and acts against the traffickers of females and children

2. Provision of rehabilitation and social reintegration for victims of human trafficking of females and children secured by laws.

3. Prevention of all forms of human trafficking of females and children in family and society.

4. Establishment of collaboration and coordination in the abolition of human trafficking of females and children between institutions in national and international levels.

Meanwhile targets of RAN-P3A are:

1. Ratification of convention against transnational organized crime and two protocols on trafficking in persons and children (The Optional Protocol to the Convention on the Rights of the Child (1989) on the Sale of Children, Child Prostitution and Child Pornography, and Protocol to Prevent, Suppress and Punish Trafficking in Persons Especially Women and Children).

2. Ratification of Law on Abolition of Human Trafficking of Females and Children, Law on Protection of Witness and Victims, Law on Abolition of Domestic Violence, Law on Protection for Migrant Workers and its Implementation Regulation.

3. Harmonization of international standards related to human trafficking into national laws by means of revision of Penal Code of Indonesia (KUHP), Indonesian Law of Criminal Procedures 
(KUHAP), Law on Marriage, Law on Immigration, and Law on Human Rights Justice.

4. Mapping of problems, situations, and criminal cases of human trafficking of females and children.

5. Improvement of quantity and quality of Crisis Center for social rehabilitation and reintegration for victims of human trafficking on females and children, especially in high-risk areas.

6. Decrease in the number of human trafficking on females and children and increase in the number of cases processed by the court, minimum $10 \%$ per year.

7. Development of model/mechanism of protection for children and females in the process of recruitment, transport, and receipt, of labour forces, especially of migrant workers.

8. Allocation of the budget from national and regional government for social rehabilitation and reintegration for victims.

9. Assured access for families, especially for females and children to get education, training, raise in salary, and social services.

10. Establishment of networking in partnership, nationally, regionally, between regions, transnationally, and.

The research data show that regional regulation on prevention and handling for victims of trafficking in females and children has been passed in 2015; however, further regulation as a requirement of a regional regulation, in order to be applicative requires Governor Regulation which has not been formulated in Jambi up to now.

One of the causes of this condition is because ASEAN Convention against Trafficking in Persons (ACTIP) has not been ratified. By ratification of ACTIP it is expected that victims of human trafficking in ASEAN can be treated, particularly in Indonesia. In the future, we will have reference system in treating victims in various destination countries as a rehabilitative step by Indonesian Government.

\section{Problems and Solutions in Treating Victims of Human Trafficking}

Considering that handling for victims of human trafficking cannot 
be done by only one institution, but should be done integrative, this field research also investigate the problems in Jambi Regional Police, Legal Bureau of Jambi City, P2TP2A of Jambi Province and Dengan pertimbangan penanganan korban trafikking ini tidak dapat dilakukan oleh satu institusi saja tetapi harus dilakukan secara terpadu maka Penelitian lapangan dilakukan pada Kepolisian Daerah Jambi, Biro Hukum Kota Jambi, P2TP2A Provinsi Jambi dan Social Services of Jambi Province.

The research data from Jambi Regional Police (POLDA Jambi) showed that in 2016, there was one case of human trafficking with 2 (two) victims, and in 2017 there were 3 (three) cases with 9 (nine) victims of human trafficking. In the field research in POLDA Jambi, researchers conducted an interview at Unit of Female and Child Services, henceforth Unit of PPA. From the interview with Suhartono, the head of Unit of PPA, and Neda Suhendar, some information was found that function of POLDA is more focused on Law Enforcement. Trafficking occurring in Jambi was in form of trafficking in female teenagers to Batam or Singapore, where Jambi serves as a transit. The policy taken by POLDA Jambi for the victims of human trafficking is to bring them to Social Services which will then bring them to the appointed social homes, or if possible return them to their family of the victims.

One problem faced by Polda in treating victims of human trafficking is the lack of clear coordination among related institutions responsible for human trafficking Results of interviews at P2TP2A (Center of Integrated Services for Females and Children), done with Asi Nofrini, Case Manager of P2TP2A, states that P2TP2A is not an authorized institution in treating victims of trafficking, but P2TP2A focuses on victims of violence on females and children, because according to her characteristics of trafficking victims are different from victims of domestic violence. Understanding that P2TP2A only serves victims of domestic violence in not really correct.

If we carefully study the definition of victims of human trafficking according to Regulation of Ministry of Social Services Number 8 Year 2002, it is stated that trafficking victims suffer from violence, 
sexual exploitation, social neglect, deportation, inability to adapt with new workplace (new country of workplace) causing disturbance of their social function. From the definition, victims of human trafficking should be considered as victims of violence making them a responsibility of $\mathrm{P} 2 \mathrm{TP} 2 \mathrm{~A}$ to be active in handling trafficking victims in Jambi. Trafficking victims' protection actually involves the community more in doing recovery through community-based therapy, where community through task force is more involved in the recovery process of victims of crime including victims of trafficking in persons. ${ }^{14}$

From this field research, the researchers observed that the handling of victims of human trafficking in Jambi Province is still carried out partially and incomprehensively. Therefore, to solve this condition, it is deemed necessary to: expansion of access to services of socialization, advocating, technical supervision, and assistance in order to stop and prevent criminal acts of human trafficking early on.

Regional government of Jambi Province needs to establish a Task Force on Handling of Victims of Human Trafficking as soon as possible, according to Regulation of Indonesian State Minister for Woman Empowerment and Child Protection Number 10 Year 2012 on Guidelines in Formation and Empowerment of Task Force for Prevention and Handling of Criminal Acts of Human Trafficking, In Article 4, it is stated that the aim of preparation of Guidelines in Formation and Empowerment of Task Force for Prevention and Handling of Criminal Acts of Human Trafficking are:

a. To provide a reference in formation and empowerment of Task Force for Prevention and Handling of Criminal Acts of Human Trafficking;

b. To unify the perception and knowledge of all stakeholders in ministry/institution and regional government on mechanism of formation and empowerment of Task Force for Prevention and Handling of Criminal Acts of Human Trafficking

14 Hafrida, Kebijakan Hukum Pidana terhadap Pengguna Narkotika, Padjadjaran Jurnal Ilmu Hukum Journal of Law, Volume 3 Nomor 1 Tahun 2016. Hal. 185-186. 
c. To increase the number and to empower Task Force for Prevention and Handling of Criminal Acts of Human Trafficking

This is in line with Indonesian Presidential Regulation Number 69 Number 2008 on Task Force for Prevention and Handling of Criminal Acts of Human Trafficking. , in Article 1 points (2) and (3) stating the definition: point (2) state the Provincial Task Force for Prevention and Handling of Criminal Acts of Human Trafficking, henceforth called Provincial Task Force is a coordinating body responsible for coordinating all efforts to prevent and handle criminal acts of human trafficking at provincial level. Point (3). Task Force for Prevention and Handling of Criminal Acts of Human Trafficking in City/Regency, henceforth called City/Regency Task Force is a coordinating body responsible for coordinating all efforts to prevent and handle criminal acts of human trafficking at city/regency level.

Article 12 (1) At Provincial level, a Provincial Task Force is established in compliance with laws and regulations. (2) Provincial Task Force works under and reports to the Governor. Article 13 (1) At city/regency level, a City/Regency Task Force is established in compliance with laws and regulation. (2) City/Regency Task Force works under and reports to Mayor/Regent.

Based on the laws and regulations elaborated above and empirical condition of the handling of human trafficking victims in Jambi Province which is not well-coordinated yet and is still done partially by each institution, Jambi Province government is deemed necessary to initiate the formation of Task Force for Prevention and Handling of Criminal Acts of Human Trafficking at Provincial and City/Regency levels.

\section{E. Closing}

Results of the research shows that the policy of regional government of Jambi Province on prevention and handling of victims of human trafficking has been done by issuing Regional Regulation of Jambi Province Number 2 Year 2015 on Prevention and Handling of Human Trafficking in Females and Children. However, in order to 
be applicative this regulation requires several Governor Regulation, which is currently unavailable. Therefore the Regional Regulation of Jambi Province Number 2 Year 2015 on Prevention and Handling of Human Trafficking in Females and Children has not been conducted well.

Empirically the handling of Trafficking victims in Jambi is still conducted partially by each related institution. POLDA Jambi stated that they were only responsible for the law enforcement action against criminal acts of human trafficking. Authority for protection should be done by other relation institutions such as Social Services and P2TP2A. Meanwhile, P2TP2A Jambi stated that the handling of victims still cannot be done because the characteristics of human trafficking victims are different from the characteristics of victims of domestic violence, and therefore handling of victims of human trafficking in females and children is beyond their range of authority.

The handling of the victims of human trafficking is still conducted partially and separately by each institution because Task Force for Prevention and Handling of Criminal Acts of Human Trafficking at provincial and city/regency level has not been formed

In order for Regional Regulation of Jambi Province Number 2 Year 2015 on Prevention and Handling of Human Trafficking in Females and Children to be applicable, a Governor Regulation in compliance with the Regional regulation needs to be formulated soon.

To improve the coordination among related institution and to enable us to understand the condition of the victims comprehensively, Task Force for Prevention and Handling of Criminal Acts of Human Trafficking at provincial and city/regency level needs to be formed.

\section{Bibliography}

Ahmad Sofian, Perlindungan Anak di Indonesia dan Solusinya, Kompas, 29-04-2010.

Barda Nawawi, Perlindungan hukum Terhadap anak Dalam Proses Peradilan, Makalah, 1992. 
Dorothy Law Nolte, Children Learn What They Live, Poem, http:/ / www.empowermenstressource.com

Hafrida, Kebijakan Hukum Pidana terhadap Pengguna Narkotika, Padjadjaran Jurnal Ilmu Hukum Journal of Law, Volume 3 Nomor 1 Tahun 2016.

Haryanto, Implementasi Keputusan Bersama tentang Penanganan ABH, Makalah pada Sosialisasi Pelaksanaan Keputusan Bersama tentang Penanganan Anak yang Berhadapan dengan Hukum (ABH) di Provinsi Jambi, tanggl 19 Nopember 2010 Novita Hotel Jambi, Kantor Pemberdayaan Perempuan dan Perlindungan Anak Provinsi Jambi, p. 1.

Jurnal Kriminologi Indonesia Vol. 4 No. I September 2005

Katarina Tomasevski. 2003. Education Denied, Zed Boooks, London. P. 45 .

Laporan Departemen Luar Negeri AS mengenai Perdagangan Manusia tahun 2012, dikutip oleh Elsa R.M Toule dan Sherly Adam dalam "Tindak Pidana Perdagangan Orang di Indonesia Sebuah Catatan Kritis

Muladi, Perlindungan Korban dalam Sistem Peradilan Pidana, Sebagaimana dimuat dalam kumpulan Karangan Hak Asasi Manusia, Politik dan Sistem Peradilan Pidana, (Semarang: Badan Penerbit Universitas Diponogoro, 1997

UN Protocol for Prevention, Suppression, and Punishment against Trafficking in Persons especially Female and Children, signed on December 2000 in Palermo, Sicily.

Riszka Ari Satriani Studi Tentang Perdagangan Manusia (Human Trafficking) Pada Remaja Putri Jenjang Sekolah Menengah Di Kota Surabaya Study Of Human Trafficking In Adolescent Girl Secondary School Level At Surabaya Bimbingan dan Konseling, Fakultas Ilmu Pendidikan, Universitas negeri Surabaya, Jurnal BK Unesa. Volume 04 Number 1, 2013. 67-78)

Soedarto, Hukum dan Hukum Pidana. $4^{\text {th }}$ ed., Alumni, Bandung, 1986.

Terry Irenewaty, Nur Hidayah, Taat Wulandari. Analisis Gender Atas Kerentanan Perempuan Dan Anak Terhadap Praktek Traffick- 
Hafrida, Nelli Herlina, \& Zulham Adamy

ing. Fis 2007

Yustika citra Mahendra: Thesis, Hubungan Internasional UGM, 2010.

Zaki Amrullah, Perlindungan Anak Belum Cukup diperhatikan di Indonesia, Deutchse Welle Indonesia, 20-11-2009.

UU No. 23 Tahun 2002 Tentang Perlindungan Anak.

UU No. 35 Tahun 2014 Perubahan atas Undang-undang Perlindungan Anak

Tribun Jambi Online, 16 Juni 2016 